\title{
A preliminary geochemical study of zircons and monazites from Deccan felsic dikes, Rajula, Gujarat, India: Implications for crustal melting
}

\author{
Nilanjan Chatterjee ${ }^{1}$ and Somdev Bhattacharjo ${ }^{2}$ \\ ${ }^{1}$ Department of Earth, Atmospheric and Planetary Sciences, Room 54-1216, Massachusetts Institute \\ of Technology, Cambridge, Massachusetts 02139, U.S.A. \\ ${ }^{2}$ Department of Geology, Brooklyn College and Graduate Center of the City University of New York, \\ Brooklyn, New York 11210, U.S.A.
}

\begin{abstract}
Zircons of $10-100 \mu \mathrm{m}$ size and monazites of up to $10 \mu \mathrm{m}$ size are present in rhyolite and trachyte dikes associated with Deccan basalts around Rajula in the southern Saurashtra Peninsula of Gujarat. On the basis of structural conformity of the felsic and basaltic dikes, K-Ar ages and trace element considerations, a previous study concluded that the felsic rocks are coeval with the Deccan Volcanics and originated by crustal anatexis. The felsic rocks contain two populations of zircons and monazites, one that crystallized from the felsic melt and the other that contains inherited crustal material. Trace element variations in the rhyolites and trachytes indicate that zircons and monazites crystallized from the felsic melts, but compositional analysis of a zircon indicates the presence of a small core possibly inherited from the crust. Hf compositional zoning profile of this zircon indicates that it grew from the host rhyolitic melt while the melt differentiated, and $\mathrm{Y}$ and LREE contents suggest that this zircon crystallized from the host melt. Pb contents of some monazites also suggest the presence of inherited crustal cores. Hence, any age determination by the U-Th-Pb isotopic method should be interpreted with due consideration to crustal inheritance. Temperatures estimated from zircon and monazite saturation thermometry indicate that the crust around Rajula may have been heated to a maximum of approximately $900^{\circ} \mathrm{C}$ by the intruding Deccan magma. Crustal melting models of other workers indicate that a 1-2 million year emplacement time for the Deccan Traps may be appropriate for crustal melting characteristics observed in the Rajula area through the felsic dikes.
\end{abstract}

\section{Introduction}

Zircon and monazite are known for their stability under diverse physical and chemical conditions. Their chemical compositions and bulk composition of their host can provide temperature constraints for the melts in which they dissolved or crystallized (Watson and Harrison 1983; Montel 1993). High elemental closure-temperatures and occurrence of only radiogenic $\mathrm{Pb}$ also make zircon and monazite ideal minerals for $\mathrm{U}-\mathrm{Th}-\mathrm{Pb}$ radioisotope dating of rocks. It is important, however, to establish the origin of zircons and monazites in a rock to correctly interpret the U-Th- $\mathrm{Pb}$ analysis results. In igneous rocks that have assimilated older continental crust, inheritance of zircons and monazites from the crust leads to discordant ages with a higher intercept in $\mathrm{Pb}$-isotope evolution diagrams corresponding to the age of the assimilated crust.

Zircons and monazites are rare in the Deccan Volcanics. Zircons have been reported from felsic rocks spatially and temporally associated with Deccan basalts in the Rajula area of

Keywords. Deccan Trap; zircon; monazite; felsic dikes; geochemistry; crustal melting. 


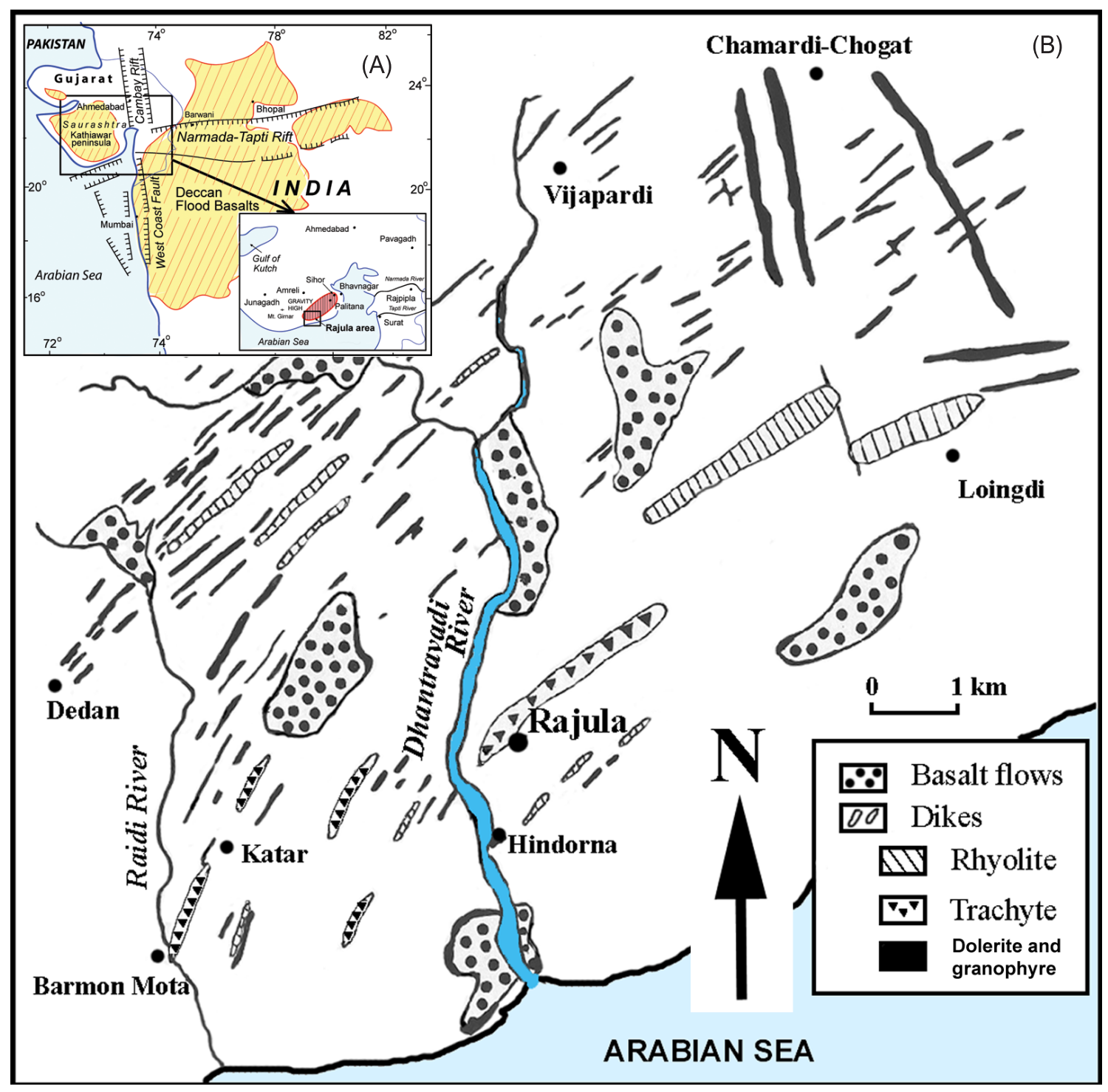

Figure 1. (A) Location of Rajula on the Saurashtra Peninsula, Gujarat, India, the extent of the Deccan flood basalts, major rift zones and gravity anomaly over Rajula-Palitana-Sihor. (B) Details of the Rajula area showing location of major dikes and flows.

Saurashtra, Gujarat, India (Chatterjee and Bhattacharji 2001, 2002). In this preliminary study we also report the occurrence of monazite in the Rajula felsic rocks, present chemical composition and petrological significance of the zircons and the monazites and explore crustal melting behavior in the Rajula area of the Deccan volcanic province.

\section{Geological setting}

The Deccan Traps of India are associated with two prominent rift zones: the north-south western continental margin rift and the east-west intraplate Narmada-Tapti Rift (figure 1). The intersection of these two rifts is a region of high heat flow and a +70 mGal gravity high (Kaila 1988), which can be explained by plume-related mantle upwelling (Bhattacharji et al 1996). The northward extension of the western continental margin rift is known as the Cambay Rift. The westward extension of the Narmada-Tapti rift is marked by ENE-WSW to NE-SW trending doleritic dike swarms outcropping as prominent ridges in the southern Saurashtra Peninsula of Gujarat, India (Auden 1949; Fedden 1884). The doleritic dikes are interspersed with clusters of rhyolite, trachyte and dacite dikes trending approximately NE-SW to NNE-SSW near Rajula (Misra 1981). The Rajula-HindornaLoingdi rhyolite dikes occur on the southwestern flank of a $+40 \mathrm{mGal}$ gravity high (Kaila 1988). Several N-S trending dolerite and granophyre (trachyte) dikes occur at Chamardi-Chogat, about 
$5 \mathrm{~km}$ northeast of Rajula (Misra 1981). These granophyre dikes are located on the western flank of the Cambay Rift and are parallel to it. At places, they cross-cut the NE-SW dikes showing offsets in some cases (figure 1) implying their relatively younger age.

\section{Geochemistry and petrography}

There is a prominent compositional gap in $\mathrm{SiO}_{2}$ (between $59 \mathrm{wt} \%$ and $67 \mathrm{wt} \%$ ), $\mathrm{MgO}$ and $\mathrm{La}$ contents between the basalts and the felsic rocks near Rajula precluding a fractional crystallization relation between the two rock types, although preliminary K-Ar dating indicates they are possibly coeval with both rock types straddling the $\sim 65 \mathrm{Ma}$ Cretaceous-Tertiary boundary (Chatterjee and Bhattacharji 2001). Trace element modeling indicates that the felsic rocks, with the exception of the trachytes of Chamardi-Chogat, originated by very high degrees of melting of the Proterozoic granitic crust into which the Deccan basaltic magma intruded (Chatterjee and Bhattacharji 2001). The heat for crustal melting was presumably supplied by the Deccan magma. The ChamardiChogat trachytes possibly originated by partial melting of previously emplaced basalts (Chatterjee and Bhattacharji 2001), with crustal contamination playing a secondary role.

The rhyolites are pink to grey with a glassy to hypocrystalline, porphyritic texture. Phenocrysts of sanidine, anorthoclase, orthoclase, plagioclase, quartz and opaques, and occasionally augite have been reported in these rocks. The granophyres (trachytes) are fine grained and consist of quartzfeldspar \pm amphibole. Zircons and monazites are present in both rhyolites and trachytes. Other accessory phases include allanite and REE rich Cacarbonates in the trachytes. In the rhyolites, the zircons are about $100 \mu \mathrm{m}$ in the longest dimension, subhedral to euhedral, and have oscillatory zoning, as seen in backscattered electron and cathodoluminescence images (figure $2 \mathrm{~A}-\mathrm{D}$ ). In the trachytic granophyres, the zircons are irregular, 10-20 $\mu \mathrm{m}$ in size, and occur as clusters (figure $2 \mathrm{E}$ and $\mathrm{F}$ ). They are sometimes associated with ilmenite and apatite. Monazite occurs in clusters of small grains up to $10 \mu \mathrm{m}$ in size.

\section{Analytical methods}

Backscattered electron and cathodoluminescence images of zircons were obtained with a JEOL733 Superprobe at the Massachusetts Institute of Technology. Chemical composition of the zircons and monazites were also obtained with the same instrument with a beam energy of $15 \mathrm{keV}$, a probe current of $300 \mathrm{nA}$ and typical counting times of $240 \mathrm{sec}$ per element. In zircons, the standard deviation $(1 \sigma)$ of counts were $1-6 \%$ for $\mathrm{Y}, 0.1 \%$ for $\mathrm{Zr}, 0.4 \%$ for $\mathrm{Hf}, 60 \%$ for $\mathrm{La}, 4-20 \%$ for Ce, 6 $60 \%$ for Nd, $2-11 \%$ for Th and $3-20 \%$ for U. In monazites, the $1 \sigma$ standard deviations of counts were $1-2 \%$ for $\mathrm{Y}, 0.1 \%$ for $\mathrm{La}, \mathrm{Ce}$ and $\mathrm{Nd}, 19 \%$ for $\mathrm{Pb}, 0.2-2 \%$ for $\mathrm{Th}$ and $18 \%$ for $\mathrm{U}$. $\mathrm{UM} \beta$ was used for $\mathrm{U}$ measurement and the counts were corrected for $\mathrm{Th}$ interference. The $\mathrm{Pb}$ counts were corrected for La, Y and Th interferences. The background positions were carefully chosen to avoid secondary peak interferences and the detectors were optimally set for pulse-height-analysis. These analytical methods are similar to those described in Pyle et al (2002). The data were reduced with the CITZAF program (Armstrong 1995) using the atomic number correction of Duncumb and Reed, Heinrich's tabulation of mass absorption coefficients and the fluorescence correction of Reed.

\section{Results}

Results of the electron microprobe analysis are presented in tables 1 and 2. The $\mathrm{HfO}_{2}$ values in zircons range $0.56-0.88$ wt $\%$ with the zircon from the trachyte showing the lowest value. These values fall at the lower end of the published range of values for zircons in terrestrial felsic igneous rocks (Belousova et al 2002; Hoskin and Schaltegger 2003), which can contain up to $12.3 \mathrm{wt} \%$ $\mathrm{HfO}_{2}$ (Uher et al 1998). Analysis of points along a core-to-rim traverse in a single zircon from a Hindorna rhyolite dike indicates a decrease in $\mathrm{U}$ and Th (except at the rim) and an increase in $\mathrm{Hf}$ from core to rim, whereas, Ce and $\mathrm{Nd}$ possibly show oscillatory behavior (figure 3 ). $\mathrm{Y}$ is low in the core, but increases and then decreases toward the rim. The $\mathrm{Th} / \mathrm{U}$ ratio decreases from 1.2 in the core to 0.4 in the rim (table 1). Except for one analysis, the $\mathrm{U}, \mathrm{Th}$ and $\mathrm{Th} / \mathrm{U}$ values of the zircons in this study (table 1) are typical of zircons found in granitoid rocks (Belousova et al 2002). In a $\mathrm{C} 1$ chondrite-normalized plot, Ce shows a positive anomaly in the zircon from trachyte (figure 4A), and the $\mathrm{Ce} / \mathrm{Nd}$ ratios are greater than 1 with a range of 1.7-5.6 (table 1 ). The REE results are thus in agreement with previous studies on zircons of granitoid and pegmatitic rocks, which indicate a characteristic positive Ce-anomaly in in situ zircon analyses related to the replacement of $\mathrm{Zr}^{4+}$ by large ionic radius- $\mathrm{Ce}^{4+}$ ion in the zircon structure (Belousova et al 2002; Hoskin and Schaltegger 2003). The zircons from rhyolite in this study are enriched in $\mathrm{Y}$ and light rare earth elements (LREE) 


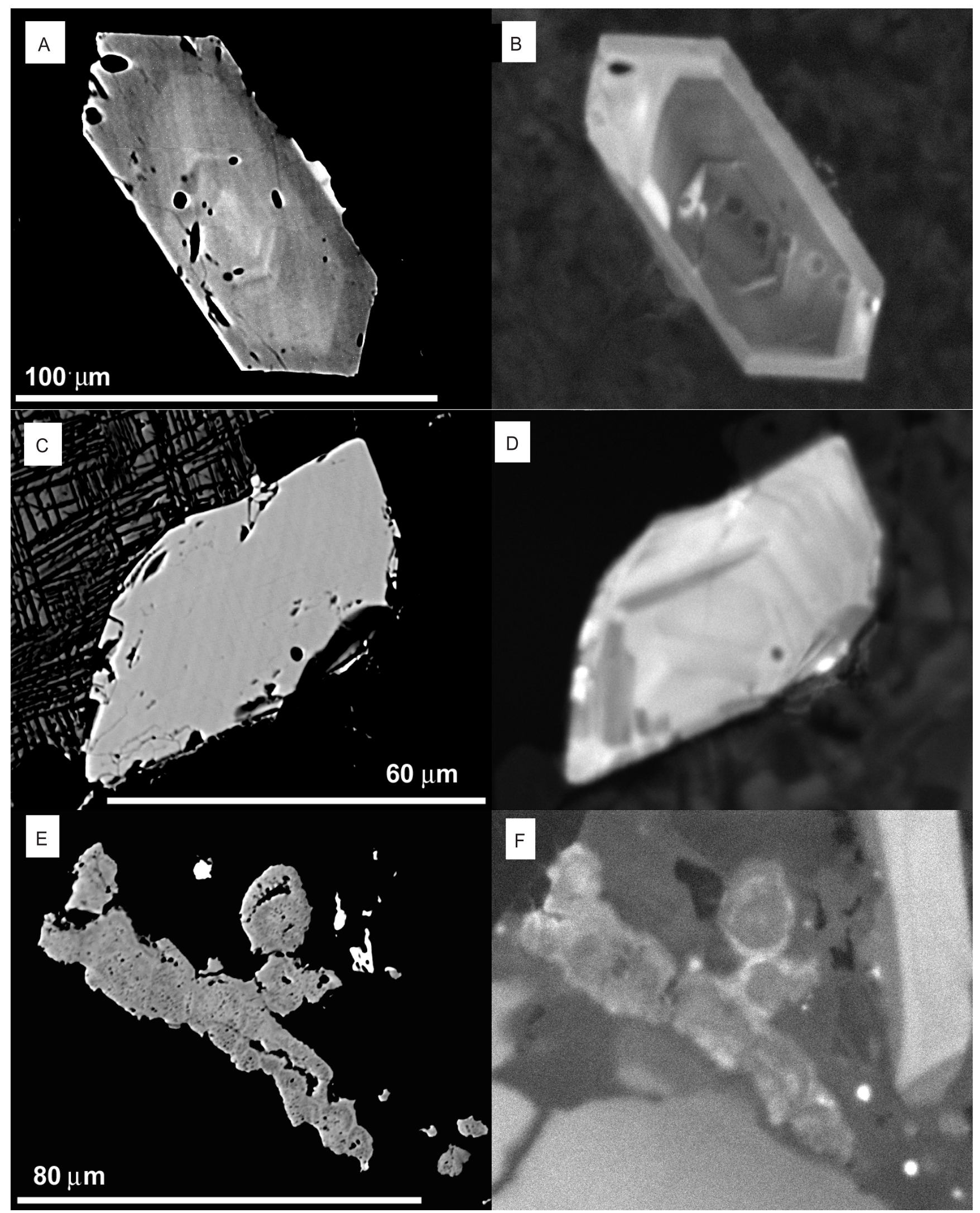

Figure 2. (A, C, E) Backscattered electron, and (B, D, F) cathodoluminescence images of zircons and surrounding phases in rhyolites (A, B: sample R-Hi-2 from Hindorna; C, D: sample Ra-4 from Rajula) and trachytes (E, F: granophyre sample CH-9 from Chamardi-Chogat) from the Rajula area of the Deccan Traps (see figure 1 for locations). In (B), points analyzed by electron microprobe from core to rim are visible. In $(\mathbf{C})$, the phase in contact with zircon is ilmenite. (F) shows a cluster of small zircons among larger grains of other phases. 
Table 1. Electron microprobe analysis of zircons in felsic rocks of Rajula area.

\begin{tabular}{|c|c|c|c|c|c|c|c|c|c|c|}
\hline & \multicolumn{3}{|c|}{ R-Hi-2 } & \multicolumn{6}{|c|}{ R-Hi-2 zircon 3} & $\begin{array}{l}\text { CH-9 } \\
\text { zircon } 1\end{array}$ \\
\hline \multicolumn{11}{|c|}{ Weight per cent } \\
\hline $\mathrm{SiO}_{2}$ & 32.62 & 31.56 & 32.08 & 31.92 & 31.95 & 32.16 & 32.02 & 31.97 & 32.46 & 30.33 \\
\hline $\mathrm{Al}_{2} \mathrm{O}_{3}$ & 0.011 & 0.005 & 0.006 & bdl & bdl & bdl & 0.003 & 0.006 & 0.025 & 0.076 \\
\hline $\mathrm{FeO}$ & 0.449 & 0.410 & 0.132 & 0.105 & 0.114 & 0.108 & 0.115 & 0.130 & 0.218 & 0.231 \\
\hline $\mathrm{CaO}$ & bdl & bdl & bdl & bdl & bdl & bdl & bdl & bdl & bdl & 0.136 \\
\hline $\mathrm{P}_{2} \mathrm{O}_{5}$ & bdl & bdl & bdl & bdl & bdl & bdl & bdl & bdl & bdl & 1.203 \\
\hline $\mathrm{Y}_{2} \mathrm{O}_{3}$ & 0.212 & 1.330 & 0.522 & 0.625 & 0.992 & 0.435 & 0.331 & 0.351 & 0.400 & 3.920 \\
\hline $\mathrm{ZrO}_{2}$ & 65.63 & 64.32 & 65.20 & 64.68 & 64.14 & 65.40 & 65.68 & 65.72 & 65.60 & 58.15 \\
\hline $\mathrm{La}_{2} \mathrm{O}_{3}$ & bdl & bdl & bdl & bdl & bdl & bdl & bdl & bdl & bdl & 0.008 \\
\hline $\mathrm{Ce}_{2} \mathrm{O}_{3}$ & 0.018 & 0.036 & 0.032 & 0.034 & 0.036 & 0.032 & 0.044 & 0.030 & 0.014 & 0.162 \\
\hline $\mathrm{Nd}_{2} \mathrm{O}_{3}$ & 0.005 & 0.017 & 0.010 & 0.006 & 0.010 & 0.008 & 0.026 & 0.007 & 0.003 & 0.071 \\
\hline $\mathrm{HfO}_{2}$ & 0.761 & 0.660 & 0.751 & 0.694 & 0.691 & 0.744 & 0.759 & 0.736 & 0.882 & 0.560 \\
\hline $\mathrm{ThO}_{2}$ & bdl & 0.210 & 0.078 & 0.166 & 0.108 & 0.034 & 0.034 & 0.029 & 0.094 & 1.287 \\
\hline $\mathrm{UO}_{2}$ & 0.011 & 0.155 & 0.104 & 0.137 & 0.106 & 0.062 & 0.053 & 0.046 & 0.220 & 0.170 \\
\hline Total & 99.72 & 98.70 & 98.92 & 98.37 & 98.15 & 98.98 & 99.07 & 99.02 & 99.91 & 96.30 \\
\hline \multicolumn{11}{|c|}{ Parts per million } \\
\hline $\mathrm{Th}$ & bdl & 1842 & 682 & 1458 & 952 & 299 & 297 & 255 & 830 & 11314 \\
\hline $\mathrm{U}$ & 97 & 1362 & 919 & 1211 & 938 & 548 & 470 & 403 & 1942 & 1496 \\
\hline $\mathrm{P}$ & bdl & bdl & bdl & bdl & bdl & bdl & bdl & bdl & bdl & 5252 \\
\hline $\mathrm{Hf}$ & 6455 & 5600 & 6368 & 5883 & 5859 & 6312 & 6436 & 6238 & 7478 & 4749 \\
\hline $\mathrm{Zr}$ & 485850 & 476200 & 482683 & 478800 & 474800 & 484200 & 486200 & 486500 & 485600 & 430450 \\
\hline $\mathrm{Y}$ & 1670 & 10471 & 4113 & 4919 & 7812 & 3425 & 2603 & 2766 & 3153 & 30870 \\
\hline $\mathrm{La}$ & bdl & bdl & bdl & bdl & bdl & bdl & bdl & bdl & bdl & 64 \\
\hline $\mathrm{Ce}$ & 154 & 307 & 272 & 293 & 311 & 274 & 379 & 256 & 118 & 1383 \\
\hline $\mathrm{Nd}$ & 39 & 147 & 85 & 52 & 82 & 72 & 221 & 57 & 29 & 613 \\
\hline$\Sigma$ LREE & 193 & 454 & 357 & 345 & 393 & 346 & 600 & 313 & 147 & 2060 \\
\hline \multicolumn{11}{|c|}{ Ratio } \\
\hline $\mathrm{Th} / \mathrm{U}$ & & 1.4 & 0.7 & 1.2 & 1.0 & 0.5 & 0.6 & 0.6 & 0.4 & 7.6 \\
\hline $\mathrm{Zr} / \mathrm{Hf}$ & 75.3 & 85.0 & 75.8 & 81.4 & 81.0 & 76.7 & 75.5 & 78.0 & 64.9 & 90.6 \\
\hline $\mathrm{Ce} / \mathrm{Nd}$ & 4.0 & 2.1 & 3.2 & 5.6 & 3.8 & 3.8 & 1.7 & 4.5 & 4.1 & 2.3 \\
\hline
\end{tabular}

$1 \sigma$ Analytical uncertainties are Y: 1-6\%, Zr: 0.1\%, Hf: 0.4\%, La: $60 \%$, Ce: $4-20 \%$, Nd: 6-60\%, Th: 2-11\% and U: 3-20\%; bdl: Below detection limit.

with Y ranging 1670-10471 ppm and total LREE ( LREE) ranging 193-600 ppm. Highest Y content previously analyzed in zircons from granitoid rocks is $6.8 \mathrm{wt} \%$ (Belousova et al 2002). The zircon from trachyte contains an order of magnitude higher $\mathrm{Y}$ and $\Sigma$ LREE. Although the Y and $\Sigma$ LREE contents of the zircons in this study are within the range found in zircons of granitoid rocks (Belousova et al 2002), the possibility of tiny xenotime or monazite inclusions within the zircon from trachyte cannot be excluded given its high $\mathrm{Ca}, \mathrm{P}$ and Th contents (table 1). In a Y versus $U$ discriminant plot (Belousova et al 2002), the zircons of this study fall in the granitoid or syenite pegmatite field.

The monazites analyzed in this study contain 0.24-0.3 La, 0.49-0.52 Ce and 0.14-0.18 Nd atoms for four atoms of oxygen (table 2). The La and
Ce values are higher than average values of these elements in metamorphic monazites (Spear and Pyle 2002). Consequently, the monazites of this study have high $\mathrm{Ce} / \mathrm{Nd}$ ratios $(2.8-3.6$, table 2$)$. The Y (except in monazite3), Th and $\mathrm{U}$ values are near the lower end of ranges given in Spear and Pyle (2002). Th and U show positive anomalies in a $\mathrm{C} 1$ chondrite-normalized plot except in one analysis (figure 4B). The high $\mathrm{Y}$ content of monazite3 (figure $4 \mathrm{~B}$, table 2 ) may be due to xenotime substitution in the monazite structure. In addition, this monazite shows no Th positive anomaly and $\mathrm{Pb}$ and $\mathrm{U}$ are below detection limit. Since $\mathrm{Pb}$ in monazite is mostly of radiogenic origin, the low $\mathrm{Pb}$ content of monazite 3 is possibly a consequence of its low $\mathrm{U}$ and $\mathrm{Th}$ content. 
Table 2. Electron microprobe analysis of monazites in a trachyte of Rajula area.

\begin{tabular}{|c|c|c|c|}
\hline & monazite 1 & monazite 2 & monazite 3 \\
\hline & \multicolumn{3}{|c|}{ Weight per cent } \\
\hline $\mathrm{SiO}_{2}$ & 0.502 & 0.448 & 0.289 \\
\hline $\mathrm{Al}_{2} \mathrm{O}_{3}$ & 0.914 & bdl & 0.531 \\
\hline $\mathrm{CaO}$ & 0.068 & 0.119 & 0.170 \\
\hline $\mathrm{P}_{2} \mathrm{O}_{5}$ & 31.10 & 30.94 & 29.74 \\
\hline $\mathrm{Y}_{2} \mathrm{O}_{3}$ & 0.269 & 0.327 & 0.827 \\
\hline $\mathrm{La}_{2} \mathrm{O}_{3}$ & 19.72 & 16.49 & 20.77 \\
\hline $\mathrm{Ce}_{2} \mathrm{O}_{3}$ & 35.49 & 34.87 & 36.32 \\
\hline $\mathrm{Nd}_{2} \mathrm{O}_{3}$ & 11.10 & 12.61 & 10.14 \\
\hline $\mathrm{PbO}_{2}$ & 0.013 & 0.014 & bdl \\
\hline $\mathrm{ThO}_{2}$ & 1.145 & 2.111 & 0.167 \\
\hline $\mathrm{UO}_{2}$ & bdl & 0.006 & bdl \\
\hline \multirow[t]{2}{*}{ Total } & 100.32 & 97.94 & 98.95 \\
\hline & \multicolumn{3}{|c|}{ Formula } \\
\hline $\mathrm{Si}$ & 0.0190 & 0.0174 & 0.0113 \\
\hline $\mathrm{Al}$ & 0.0408 & & 0.0245 \\
\hline $\mathrm{Ca}$ & 0.0028 & 0.0049 & 0.0071 \\
\hline $\mathrm{P}$ & 0.9972 & 1.0196 & 0.9850 \\
\hline $\mathrm{Y}$ & 0.0054 & 0.0068 & 0.0172 \\
\hline $\mathrm{La}$ & 0.2755 & 0.2367 & 0.2996 \\
\hline $\mathrm{Ce}$ & 0.4922 & 0.4969 & 0.5201 \\
\hline $\mathrm{Nd}$ & 0.1502 & 0.1753 & 0.1416 \\
\hline $\mathrm{Pb}$ & 0.0001 & 0.0001 & \\
\hline $\mathrm{Th}$ & 0.0099 & 0.0187 & 0.0015 \\
\hline $\mathrm{U}$ & & 0.0001 & \\
\hline $\mathrm{O}$ & 4 & 4 & 4 \\
\hline \multirow[t]{2}{*}{ ¿Cation } & 1.9930 & 1.9760 & 2.0080 \\
\hline & \multicolumn{3}{|c|}{ Parts per million } \\
\hline Th & 10062 & 18549 & 1471 \\
\hline $\mathrm{U}$ & bdl & 51 & bdl \\
\hline $\mathrm{Pb}$ & 113 & 122 & bdl \\
\hline $\mathrm{P}$ & 135729 & 135031 & 129794 \\
\hline $\mathrm{Y}$ & 2115 & 2577 & 6515 \\
\hline $\mathrm{La}$ & 168200 & 140600 & 177100 \\
\hline $\mathrm{Ce}$ & 303000 & 297700 & 310100 \\
\hline $\mathrm{Nd}$ & 95200 & 108100 & 86900 \\
\hline \multirow[t]{2}{*}{$\Sigma$ LREE } & 566400 & 546400 & 574100 \\
\hline & & Ratio & \\
\hline $\mathrm{Th} / \mathrm{U}$ & & 363.7 & \\
\hline $\mathrm{Th} / \mathrm{Pb}$ & 89.0 & 152.0 & \\
\hline $\mathrm{Ce} / \mathrm{Nd}$ & 3.2 & 2.8 & 3.6 \\
\hline
\end{tabular}

All analyses are from sample CH-9;

$1 \sigma$ Analytical uncertainties are Y: $1-2 \%, \mathrm{La}, \mathrm{Ce}, \mathrm{Nd}: 0.1 \%$, Pb: $19 \%$, Th: $0.2-2 \%$ and U: $18 \%$;

bdl: Below delection limit.

\section{Discussion}

Field relations such as coexistence and structural conformity of the rhyolite dikes with Deccan basaltic dikes, rare presence of dacite and andesite that resulted from crustal assimilation by Deccan basalt and K-Ar age determinations indicate that the rhyolites near Rajula are coeval with the Deccan basalts. Here we evaluate whether the zircons and monazites in the felsic rocks near Rajula can be used for precise U-Th- $\mathrm{Pb}$ dating.

Since the Rajula rhyolites originated by crustal anatexis (Chatterjee and Bhattacharji 2001), it is important to determine whether the zircons and monazites within them are inherited from the crust or crystallized from the rhyolitic melt. Relative variation of trace elements in the felsic rocks near Rajula indicates that zircon, monazite, apatite and ilmenite were involved in the differentiation of the felsic rocks (figure 5). A positive correlation of $\mathrm{Zr}$ with $\mathrm{Y}$ and $\mathrm{Ce}$ (in each sub-area) is possibly related to zircon fractionation, whereas, a positive correlation of $\mathrm{P}_{2} \mathrm{O}_{5}$ with $\mathrm{CaO}$ and $\mathrm{Ce}$ may be due to apatite and monazite fractionation. Both $\mathrm{Zr}$ and $\mathrm{P}_{2} \mathrm{O}_{5}$ are also positively correlated with $\mathrm{TiO}_{2}$ possibly indicating ilmenite co-crystallization. A negative correlation of $\mathrm{Zr}$ with $\mathrm{Th}$ and $\mathrm{P}_{2} \mathrm{O}_{5}$ perhaps indicates a lesser role of monazite/apatite compared to zircon in the differentiation of these rocks.

\subsection{Zircon}

Zircon plays an important role in fractionation of rhyolites (Evans and Hanson 1993). Hf concentration in zircon increases with magmatic differentiation (Wark and Miller 1993). In a zircon from Hindorna (figure 2), Hf increases from core to rim (figure 3) perhaps indicating fractional crystallization of this zircon during the differentiation of the host liquid. For Ce, Nd and Y concentrations measured at the core and rim of this zircon (figure 3), distribution coefficients ( ${ }^{\text {zircon } / \text { melt }} D_{M}$, where $M$ is $\mathrm{Ce}, \mathrm{Nd}$ or $\mathrm{Y}$ ) of $0.9-2.3$ for Ce, $0.5-1.1$ for $\mathrm{Nd}$ and $43-87$ for $\mathrm{Y}$ are required to reproduce the $\mathrm{Ce}, \mathrm{Nd}$ and $\mathrm{Y}$ concentrations of the Hindorna rhyolites (as in Chatterjee and Bhattacharji 2001). These values compare favorably with the zircon/melt $D_{M}$ determined by Thomas et al (2002, 2003) on quartz-diorites and rhyolites. Hence, it is possible that the zircon of figure 2 crystallized from a Hindorna rhyolitic melt. However, the relatively low $\mathrm{Y}$ in the center compared to the other parts of the zircon in figure 2 may imply a small, inherited core from the crust. Preliminary U-Pb isotopic analyses (unpublished data) also yield concordant 


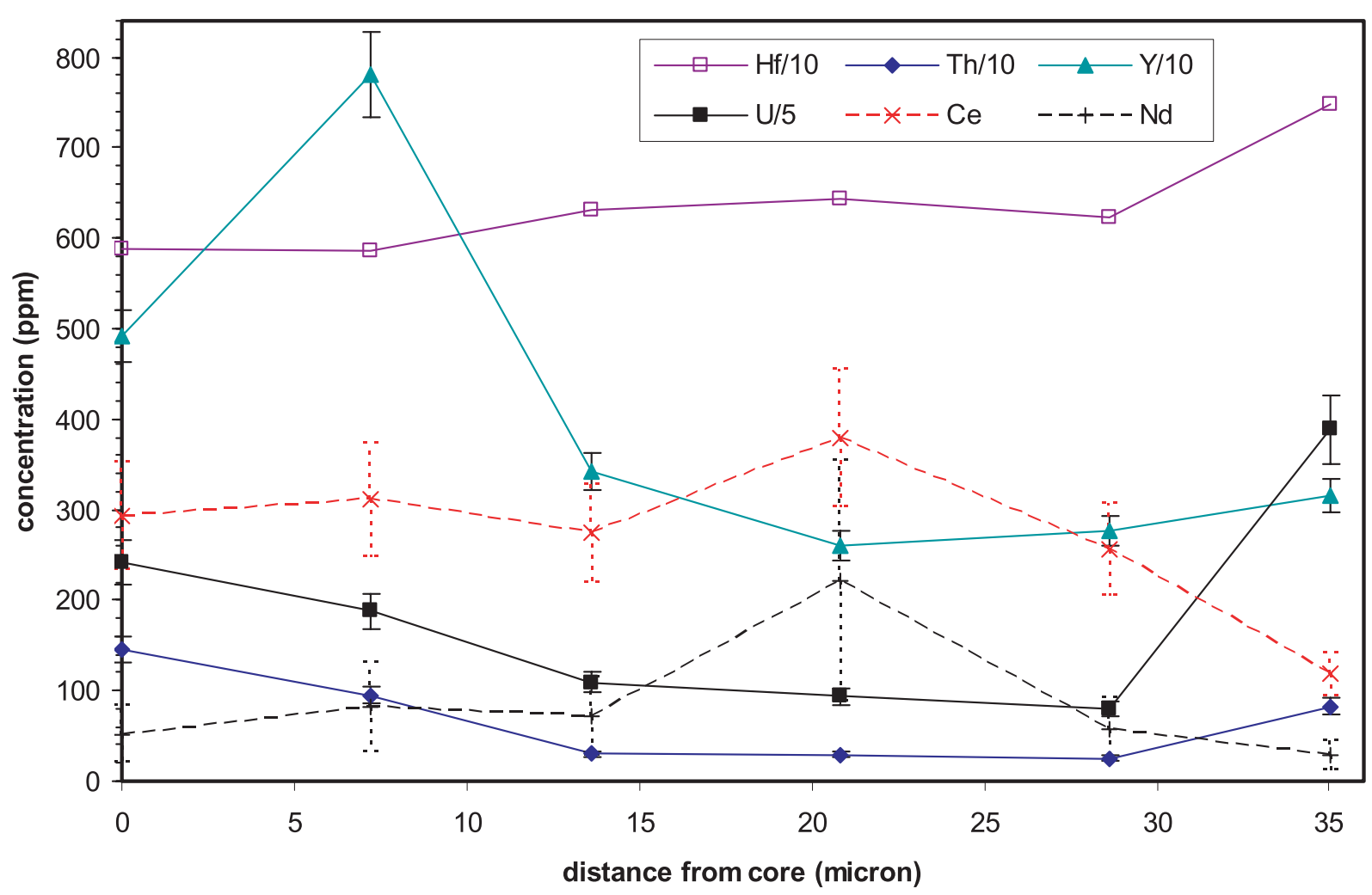

Figure 3. Core-to-rim traverse showing elemental concentrations in a zircon from Hindorna rhyolite R-Hi-2 (figure 2A, B). Error bars represent the highest observed analytical uncertainties in terms of $1 \sigma$ standard deviation of counts (see section on analytical methods).
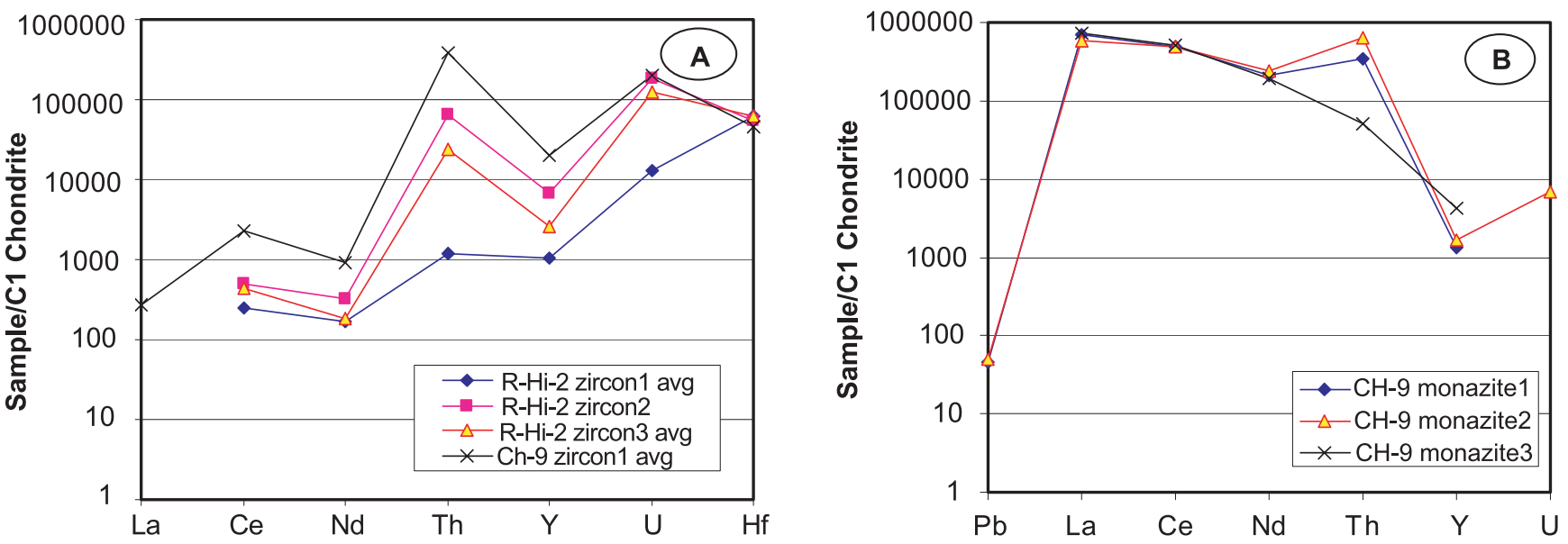

Figure 4. $\quad$ C1 chondrite-normalized (McDonough and Sun 1995) incompatible element contents of (A) zircons and (B) monazites from felsic rocks of the Rajula area. For analytical uncertainties, see section on analytical methods.

as well as discordant ages in a Pb-isotope evolution diagram, possibly due to the older inherited crustal cores.

The experimental study of Watson and Harrison (1983) suggests that Zr-saturated rhyolitic melts contain approximately $500-1500 \mathrm{ppm} \mathrm{Zr}$ at $930^{\circ} \mathrm{C}$, and $1200-3500 \mathrm{ppm} \mathrm{Zr}$ at $1020^{\circ} \mathrm{C}$. Zr content of the Rajula rhyolites range $308-517$ ppm (Chatterjee and Bhattacharji 2001). The zircon saturation equation of Watson and Harrison (1983) predicts that zircon with Zr-contents as in table 2 will be dissolved in Rajula (Hindorna) rhyolitic and trachytic melts above approximately $890^{\circ} \mathrm{C}$ and $868^{\circ} \mathrm{C}$, respectively. Since inherited crustal cores 

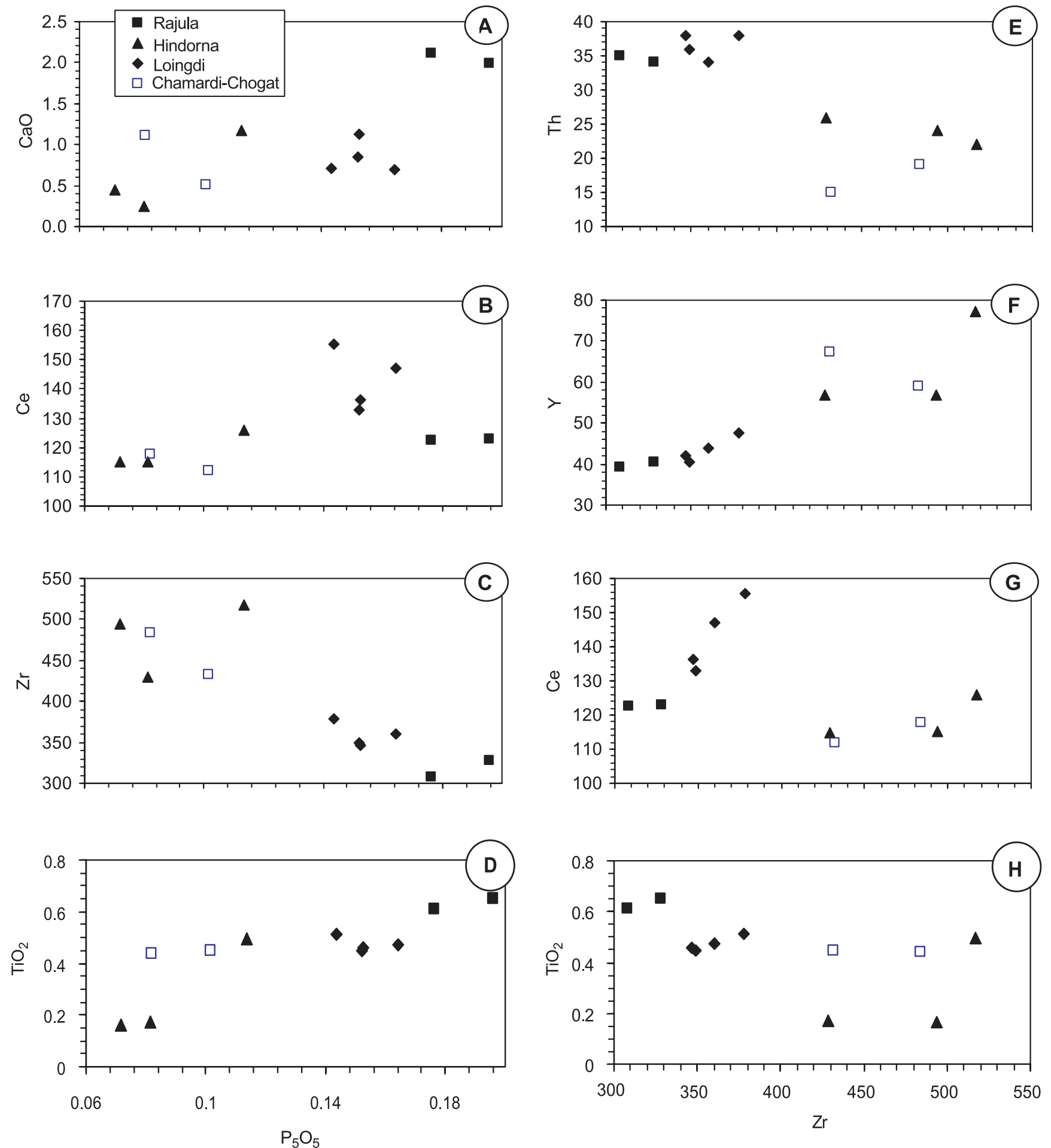

Figure 5. Trace element variations as a function of $\mathrm{P}_{2} \mathrm{O}_{5}(\mathrm{~A}-\mathrm{D})$ and $\mathrm{Zr}(\mathrm{E}-\mathrm{H})$ concentrations in felsic rocks of the Rajula area (data from Chatterjee and Bhattacharji 2001). Elemental concentrations are in ppm and oxides are in wt\%.

are probably present in the zircons, these calculated temperatures on the basis of $\mathrm{Zr}$-contents might represent approximate maximum temperatures attained by the crustal country rocks of this region. However, kinetics also played a role on the survival of zircon cores during dissolution and slightly higher temperatures cannot be ruled out.

\subsection{Monazite}

Monazite solubility depends on temperature, composition and $\mathrm{H}_{2} \mathrm{O}$-content of the liquid (Rapp and Watson 1986; Montel 1986). The monazite saturation equation of Montel (1993) predicts that the Rajula rhyolitic and trachytic melts (bulk REE 
contents from Chatterjee and Bhattacharji 2001) will dissolve monazite above $855-915^{\circ} \mathrm{C}$ and $805^{-}$ $818^{\circ} \mathrm{C}$, respectively, under anhydrous conditions. If loss-on-ignition values $(0.8-2.9$ wt\%, Chatterjee and Bhattacharji 2001) of the rhyolites and trachytes are assumed to be the $\mathrm{H}_{2} \mathrm{O}$ contents of the melts, the saturation temperatures will be lower by about $50^{\circ} \mathrm{C}$. These temperatures are in good agreement with the zircon saturation temperatures predicted with the equation of Watson and Harrison (1983). Monazite stability, however, depends on complex REE interactions among all different REE-bearing phases that can occur in the crust (Bea 1996).

Whether or not crustal monazite was completely consumed during melting can be evaluated from the measured monazite compositions (table 2 ). $\mathrm{Pb}$ was detected and analyzed in two of the monazites. Assuming this $\mathrm{Pb}$ is fully of radiogenic origin, the $\mathrm{Pb}$-evolution equation (e.g., Montel et al 1996) yields chemical ages of 252 and $147 \mathrm{Ma}$ for these two monazites. Even though these ages are highly uncertain because of only two analyses and high uncertainties in $\mathrm{Pb}$ and $\mathrm{U}$ measurements, they prove that these monazites predate the Deccan event and must have been inherited from the crust by the felsic melt. Monazite crystallization as overgrowths, however, cannot be ruled out because of a positive correlation between $\mathrm{Ce}$ and $\mathrm{P}_{2} \mathrm{O}_{5}$ in the bulk composition of the samples of Rajula area (figure $5 \mathrm{~B})$. For cooling rates of $10-1000^{\circ} \mathrm{C} / \mathrm{Ma}, \mathrm{Pb}$ is essentially immobile in $10 \mu \mathrm{m}$-sized monazites up to temperatures of $925-1050^{\circ} \mathrm{C}$ (Cherniak et al 2004). For isothermal heating, however, a $10 \mu \mathrm{m}-$ sized monazite grain would lose approximately $15 \%$ of its $\mathrm{Pb}$ by volume diffusion if heated at $900^{\circ} \mathrm{C}$ for 1-2 million years (Cherniak et al 2004), which is the approximate duration of Deccan eruptions. Since the melt temperature could have been up to $915^{\circ} \mathrm{C}$ (see above) and most of the monazites in these rocks are less than $10 \mu \mathrm{m}$ in size, it is plausible that some $\mathrm{Pb}$ has been lost from the monazites. These monazites may thus be older than their calculated chemical ages.

\subsection{Crustal melting around Rajula}

Composition of primitive picrites of Gujarat yields potential temperatures of $1430-1468^{\circ} \mathrm{C}$ for the intruding Deccan magma (Melluso et al 1995). Yet, zircon and monazite saturation thermometry indicates that the maximum temperatures attained by the crust near Rajula were probably not much higher than $900^{\circ} \mathrm{C}$. Annen and Sparks (2002) parameterized experimental data on crustal melting to predict melt fraction and temperature of crust due to repetitive emplacement of basalts at different time intervals. These authors predict that a fertile upper crust can be heated to $900^{\circ} \mathrm{C}$ and melted $65 \%$ at $20 \mathrm{~km}$ depth by dry basalt at $1300^{\circ} \mathrm{C}$ intruding at the rate of $50 \mathrm{~m}$ every 10000 years for 1.6 million years. Deccan magma production rates are uncertain, but rates of 26-40 m per 10000 years (Sen 1995, assuming an aerial extent of 1 million $\mathrm{km}^{2}$ ) were possible. If the Deccan Traps were emplaced over 1-2 million years, it is possible that picritic magma at $\sim 1450^{\circ} \mathrm{C}$ heated granitic crust to $\sim 900^{\circ} \mathrm{C}$ and produced high fractions of melt. We have shown through trace element considerations that high fractions of melting occurred in the crust around Rajula (Chatterjee and Bhattacharji 2001), and through zircon and monazite saturation thermometry that the crust was heated to about $900^{\circ} \mathrm{C}$. It must be noted, however, that only minor volumes of felsic volcanic rocks are exposed among the Deccan Volcanics. Hence, melting was probably localized and aided by local crustal heterogeneities. A 1-2 million year emplacement time for the Deccan basalts seems appropriate since faster emplacement rates would heat and melt the crust quickly (Annen and Sparks 2002) and produce a more extensive felsic province.

\section{Conclusion}

The felsic dikes associated with Deccan Volcanics near Rajula, Gujarat, India contain zircons that crystallized from anatectic felsic melts, although small cores inherited from the crust are possibly present. Hf zoning profile of a zircon suggests that it grew from the host melt during meltdifferentiation, and $\mathrm{Y}$ and LREE contents indicate that this zircon may have crystallized from the host melt. Pb-content of monazites in trachytes indicates that inherited crustal cores are most likely present. Monazite overgrowth rims may have crystallized from the felsic melts. Zircons and monazites of the felsic rocks around Rajula thus may be analyzed for U-Th-Pb isotopes for age determination with due consideration to crustal inheritance. Temperature estimates from zircon and monazite saturation thermometry indicate that the crust around Rajula may have been heated to a maximum of approximately $900^{\circ} \mathrm{C}$ by the intruding Deccan magma. Crustal melting models indicate that a 1-2 million year emplacement time for the Deccan Traps may be appropriate for crustal melting characteristics observed in the Rajula area through the study of the felsic intrusive rocks.

\section{Acknowledgements}

We thank Dr. Daniele Cherniak of RPI, Troy, USA, Dr. William L Griffin of Maquarie University, 
Australia and an anonymous reviewer for constructive comments and helpful suggestions to improve the manuscript during peer review. Field study and sample collection efforts were financially supported by a Faculty Research Grant of the City University of New York and NSF (International) grants to SB, who also thanks the Director, Librarian and Assistant Librarian of Geophysical Laboratory, Carnegie Institution of Washington D.C. for making library facilities available.

\section{References}

Annen C and Sparks R S J 2002 Effects of repetitive emplacement of basaltic intrusions on thermal evolution and melt generation in the crust; Earth Planet. Sci. Lett. 203 937-955

Armstrong J T 1995 CITZAF - A package for correction programs for the quantitative electron microbeam x-ray analysis of thick polished materials, thin-films and particles; Microbeam Analysis 4 177-200

Auden J B 1949 Dykes of western India; Transactions of National Institute of Science, India 3 123-157

Bea F 1996 Residence of REE, Y, Th and U in granites and crustal protoliths: implications for the chemistry of crustal melts; J. Petrol. 37 521-552

Belousova E A, Griffin W L, O'Reilly S Y and Fisher N I 2002 Igneous zircon: trace element composition as an indicator of source rock type; Contrib. Mineral. Petrol. $143602-622$

Bhattacharji S, Chatterjee N, Wampler J M, Nayak P N and Deshmukh S S 1996 Indian intraplate and continental margin rifting, lithospheric extension, and mantle upwelling in Deccan flood basalt volcanism near the $\mathrm{K} / \mathrm{T}$ boundary: evidence from mafic dike swarms; J. Geol. 104 379-398

Chatterjee N and Bhattacharji S 2001 Origin of the felsic dikes and basaltic dikes and flows in the Rajula-PalitanaSihor area of the Deccan Traps, Saurashtra, India: a geochemical and geochronological study; International Geology Review 43 1094-1116

Chatterjee N and Bhattacharji S 2002 A geochemical and geochronological study of felsic dikes associated with the northwestern Deccan basalts of southern Saurashtra, India; EOS Transactions, American Geophysical Union, Spring Meeting Supplement Abstract V21B-10 83/19 S365

Cherniak D J, Watson E B, Grove M and Harrison T M $2004 \mathrm{~Pb}$ diffusion in monazite: a combined RBS/SIMS study; Geochimica et Cosmochimica Acta 68/4 829-840

Evans O C and Hanson G N 1993 Accessory mineral fractionation of rare earth element (REE) abundances in granitic rocks; Chemical Geology 110 69-93

Fedden F 1884 Geology of Kathiawar peninsula in Gujarat; Memoir Geological Survey of India 21

Hoskin P W O and Schaltegger U 2003 The composition of zircon and igneous and metamorphic petrogenesis. In: "Zircon", Reviews in Mineralogy \& Geochemistry, (eds) J M Hanchar and P W O Hoskin, Mineralogical Society of America $\mathbf{5 3}$ 27-62

Kaila K L 1988 Mapping the thickness of Deccan trap flows in India from DSS studies and inferences about a hidden Mesozoic basin in Narmada-Tapti region. In: "Deccan
Flood Basalts", Geological Society of India (Bangalore) Memoir 10 96-116

McDonough W F and Sun S S 1995 The composition of the Earth. In: "Chemical evolution of the mantle" (eds) W F McDonough, N T Arndt and S Shirey Chemical Geology 120 223-253

Melluso L, Beccaluva L, Brotzu P, Gregnanin A, Gupta A K, Morbidelli L and Traversa G 1995 Constraints on the mantle sources of the Deccan Traps from the petrology and geochemistry of the basalts of Gujarat state (western India); J. Petrol. 36 1393-1432

Misra K S 1981 The tectonic setting of Deccan volcanics in southern Saurashtra and northern Gujarat. In: "Deccan volcanism and related basalt provinces in other parts of the world" (eds) K V Subbarao and R N Sukheswala Geol. Soc. India (Bangalore) Memoir 3 81-86

Montel J-M 1986 Experimental determination of the solubility of Ce-monazite in $\mathrm{SiO}_{2}-\mathrm{Al}_{2} \mathrm{O}_{3}-\mathrm{K}_{2} \mathrm{O}-\mathrm{Na}_{2} \mathrm{O}$ melts at $800^{\circ} \mathrm{C}, 2 \mathrm{kbar}$, under $\mathrm{H}_{2} \mathrm{O}$-saturated conditions; Geology 14 659-662

Montel J-M 1993 A model for monazite/melt equilibrium and application to the generation of granitic magmas; Chemical Geology 110 127-146

Montel J-M, Foret S, Veschambre M, Nicollet C and Provost A 1996 Electron microprobe dating of monazite; Chemical Geology 131 37-53

Pyle J M, Spear F S and Wark D A 2002 Electron microprobe analysis of REE in apatite, monazite and xenotime: protocols and pitfalls. In: "Phosphates: geochemical, geobiological and materials importance", Reviews in Mineralogy \& Geochemistry, (eds) M J Kohn, J Rakovan and J M Hughes, Mineralogical Society of America 48 337-362

Rapp R P and Watson E B 1986 Monazite solubility and dissolution kinetics: implications for the thorium and light rare earth chemistry of felsic magmas; Contrib. Mineral. Petrol. 94 304-316

Sen G 1995 A simple petrologic model for the generation of Deccan Trap magmas; International Geology Review $\mathbf{3 7}$ $825-850$

Spear F S and Pyle J M 2002 Apatite, monazite and xenotime in metamorphic rocks. In: "Phosphates: geochemical, geobiological and materials importance", Reviews in Mineralogy \& Geochemistry, (eds) M J Kohn, J Rakovan and J M Hughes, Mineralogical Society of America 48 293-336

Thomas J B, Bodnar R J, Shimizu N and Sinha A K 2002 Determination of zircon/melt partition coefficients from SIMS analysis of melt inclusions in zircon; Geochimica et Cosmochimica Acta 66 2887-2901

Thomas J B, Bodnar R J, Shimizu N and Chesner C A 2003 Melt inclusions in zircon. In: "Zircon", Reviews in Mineralogy \& Geochemistry, (eds) J M Hanchar and P W O Hoskin, Mineralogical Society of America $\mathbf{5 3}$ 63-87

Uher P, Breiter K, Kleeka M and Pivec E 1998 Zircon in highly evolved Hercynian Homolka Granite, Moldanubian zone, Czech Republic: indicator of magma source and petrogenesis; Geologica Carpathica 49 151-160

Wark D A and Miller C F 1993 Accessory mineral behavior during differentiation of a granite suite: monazite, xenotime and zircon in Sweetwater Wash pluton, southeastern California, U.S.A.; Chemical Geology 110 49-67

Watson E B and Harrison T M 1983 Zircon saturation revisited: temperature and composition effects in a variety of crustal magma types; Earth Planet. Sci. Lett. 64 295-304 